\title{
Perspectives on the role of the human gut microbiota and its modulation by pro- and prebiotics
}

\author{
Toni Steer*, Hollie Carpenter, Kieran Tuohy and Glenn R. Gibson \\ Food Microbial Sciences Unit, School of Food Biosciences, \\ The University of Reading, Whiteknights, PO Box 226, Reading, RG6 6AP, UK
}

\begin{abstract}
One of the most topical areas of human nutrition is the role of the gut in health and disease. Specifically, this involves interactions between the resident microbiota and dietary ingredients that support their activities. Currently, it is accepted that the gut microflora contains pathogenic, benign and beneficial components. Some microbially induced disease states such as acute gastroenteritis and pseudomembranous colitis have a defined aetiological agent(s). Speculation on the role of microbiota components in disorders such as irritable bowel syndrome, bowel cancer, neonatal necrotising enterocolitis and ulcerative colitis are less well defined, but many studies are convincing. It is evident that the gut microflora composition can be altered through diet. Because of their perceived health-promoting status, bifidobacteria and lactobacilli are the commonest targets. Probiotics involve the use of live micro-organisms in food; prebiotics are carbohydrates selectively metabolized by desirable moieties of the indigenous flora; synbiotics combine the two approaches. Dietary intervention of the human gut microbiota is feasible and has been proven as efficacious in volunteer trials. The health bonuses of such approaches offer the potential to manage many gut disorders prophylactically. However, it is imperative that the best methodologies available are applied to this area of nutritional sciences. This will undoubtedly involve a genomic application to the research and is already under way through molecular tracking of microbiota changes to diet in controlled human trials.
\end{abstract}

Gut: Microbiota: Health: Disease

\section{Introduction}

In this review, the impact of the resident microflora on human gastrointestinal health and disease is addressed. Attention is paid to current understanding of the role of key members of

\footnotetext{
Abbreviations: ACF, aberrant crypt foci; CD, Crohn's disease; CFU, colony-forming units; DGGE, denaturing gradient gel electrophoresis; FISH, fluorescent in situ hybridisation; FOS, fructo-oligosaccharides; HFA, human-microflora-associated; IBD, inflammatory bowel disease; IBS, irritable bowel syndrome; NEC, neonatal necrotising enterocolitis; PCR, polymerase chain reaction; SCFA, short-chain fatty acids; UC, ulcerative colitis.

*Corresponding author: Toni E. Steer, fax + 44 (0) 118 9357222, email t.e.steer@reading.ac.uk
} 
the microflora in gastrointestinal disorders and infections. Similarly, the ameliorating effect of what are seen as beneficial micro-organisms in the maintenance of gastrointestinal health is assessed. The impact of modern microbiological and molecular biological methodologies on improving our understanding of the gut microbial ecology is also discussed.

\section{Microbial ecology of the human gastrointestinal tract}

The human gastrointestinal tract is made up of complex consortia of micro-organisms, which colonise the length of the gut. At birth, the gastrointestinal tract is essentially germ free, with initial colonisation occurring during birth or shortly afterwards. First colonisers such as the facultative Gram-positive cocci, enterobacteria and lactobacilli soon give way to more strictly anaerobic species and, in the case of breast-fed infants, a microflora dominated by bifidobacteria (Stark \& Lee, 1982; Campbell \& Jones, 1996; Levy, 1998). Upon weaning, the microflora increases in diversity and, after about two years, the composition is substantially equivalent to that of adults in species diversity and population profile (Conway, 1995).

The stomach is home to a relatively small number of micro-organisms, with numbers typically at $10^{3}$ colony-forming units (CFU)/g contents (Gibson \& Beaumont, 1996). In the small intestine, bacterial numbers and diversity are limited by a fast transit time and digestive secretions such as bile acids. In the lower reaches of the small gut, the movement of gut contents slows and sizeable microbial populations are observed (about $10^{6} \mathrm{CFU} / \mathrm{ml}$ ). The colonic microflora is extremely complex, being made up of more than 500 different species (Gibson \& Beaumont, 1996). Climax microbial populations can reach up to $10^{12} \mathrm{CFU} / \mathrm{g}$ lumen contents (Conway, 1995; Gibson et al. 2000). The microflora is dominated by strict anaerobes, which ferment endogenous and exogenous substrates (Macfarlane \& McBain, 1999). Shortchain fatty acids (SCFA), especially acetate, propionate, butyrate and lactate, contribute towards energy metabolism of the large gut mucosa and colonic cell growth, and are also metabolised systemically by host tissues such as the liver, muscle and brain. The fermentative capabilities of the colonic microflora also contribute towards large bowel digestive function, acting on recalcitrant compounds of dietary origin and on host secretions, allowing recovery of nutrients otherwise lost to the host (Macfarlane \& McBain, 1999). The colonic microflora is involved in bowel motility, enterohepatic cycling of primary bile acids and possibly the metabolism of cholesterol, resulting in the production of faecal neutral sterols (Rafter, 1995). Species diversity and an array of microbial interactions lead to a high degree of homoeostasis and self-regulation in the colonic microflora (Veilleux \& Rowland, 1981). Stability of the microflora effectively limits the capacity of invading micro-organisms, including pathogens, to colonise the gut, giving rise to what has been termed 'colonisation resistance' (Hentges, 1992).

The colonic microbiota has been linked to the aetiology of certain disorders such as inflammatory bowel disease, gastroenteritis and colon cancer (Gibson \& Macfarlane, 1994; Chadwick \& Anderson, 1995). Pre-carcinogenic compounds and xenobiotics ingested in food are acted upon by enzyme activities of the colonic microflora (Rowland, 1995). Such reactions may result in the production of carcinogens or their detoxification. Similarly, $\mathrm{H}_{2} \mathrm{~S}$ produced by sulfate-reducing bacteria in the human gut is highly toxic and may also onset ulcerative colitis (Gibson \& Beaumont, 1996). Conversely, SCFA produced by intestinal bacteria are thought to guard against colon cancer (Rowland, 1995).

The intestinal immune system, in a healthy subject, exists in a state of homoeostasis with

the microflora. This may reflect the beneficial role of the gut microflora and the evolution of 'indigenous' micro-organisms alongside their human host (Conway, 1995). 


\section{The resident microflora and gastrointestinal disease}

\section{Irritable bowel syndrome}

Irritable bowel syndrome (IBS) affects up to $20 \%$ of the general population and is a huge concern for the medical profession. It has no diagnostic markers but symptoms include excessive flatus, bloating and variable bowel habit (Parker et al. 1995). The aetiology of IBS is unknown although it has been suggested that the gut microflora have a role in development. A study carried out by Balsari et al. (1982) examined the microbiological profile of stool samples from twenty patients with IBS and twenty control subjects. Coliforms, lactobacilli and bifidobacteria were all decreased in IBS patients.

King et al. (1998) carried out a crossover controlled study of control and IBS subjects which involved switching between a standard diet (Western European type diet) and an exclusion diet (where dairy products were replaced with soya products and cereals other than rice were eliminated) while gas production was measured. It was found that colonic production of gas, particularly of hydrogen, was greater in subjects with IBS, indicating gut dysfunction.

A further group of IBS patients, who received repeated antibiotic therapy, responded well to a treatment designed to lower the intestinal load of yeast (King et al. 1998) since Candida albicans has also been implicated as a possible agent in pathogenesis. In this context, our (unpublished) studies have shown that antimicrobials designed to clear yeast infection during IBS or thrush, or both, can have an adverse effect on the normal gut flora. In particular, certain species of beneficial lactobacilli are affected, suggesting that probiotic or prebiotic therapy (see later) should be considered to guard against this.

\section{Inflammatory bowel disease}

Inflammatory bowel disease (IBD) encompasses the conditions of Crohn's disease (CD), ulcerative colitis (UC) and non-specific colitis. Affecting up to two million people worldwide, $\mathrm{CD}$ and UC are chronic relapsing inflammatory disorders of the intestine, with the former affecting any site along the gastrointestinal tract whereas the latter is confined to the colon. The symptoms differ in some respects but both involve a gradual onset, disturbance in bowel habit and mucosal inflammation (Chadwick \& Anderson, 1995).

The gut microflora has been implicated in pathogenesis of IBD. Lower numbers of Lactobacillus spp. and Bifidobacterium spp. have been reported for patients with CD (Chadwick \& Anderson, 1995). Similarly, the faecal microflora of patients with CD have higher numbers of coccoid anaerobes than are found in healthy individuals. Investigations carried out by Onderdonk et al. (1981) showed that obligate anaerobes are a necessary component for the development of experimental UC.

A number of chronic intestinal conditions respond well to a change in the patient's diet, in particular to the elimination of refined carbohydrates. More than $50 \%$ of patients with CD reacted positively to such diets, suggesting that microbial fermentation in the gut is a factor in the pathogenesis of the disease (Parker et al. 1995).

Work in our laboratory is determining the role of sulfate-reducing bacteria in UC. This was driven by early results showing that most people with UC carry sulfate reducers in their stools that have the potential to generate high quantities of toxic sulfide (Gibson et al. 1991). Colitic sulfate-reducing bacterial isolates are more stable than equivalent strains taken from the 'healthy' gut, when certain physiological parameters indicative of UC are imposed on them (Gibson et al. 1991); these include fast transit time and low substrate availability. Our data have 
shown that $98 \%$ of colonocyte activity is lost when sulfate-reducing bacteria invade them. We are currently in the process of applying molecular studies to pathogenesis with a view to dietary management of the disorder.

Despite extensive studies carried out on the bacterial populations present in faeces, relatively little is known about the bacteriology of the mucosal-associated microflora. It may well be that such a microflora has particular functions pertaining to the host but, as yet, the metabolic and health-related significance remains unknown (Macfarlane et al. 1999). The mucosal microflora has been implicated in IBD, owing to the high recovery rate (40-50\%) of L-forms (otherwise known as cell-wall-deficient organisms or spheroplasts) in patients with IBD compared with control subjects. These L-forms are resistant to host defences, probably because they lack cell wall antigens, facilitating intracellular survival. Such organisms have been found in the eyes of patients with UC and CD with idiopathic uveitis, suggesting that similar infections of the gut may be responsible for intestinal disease (Chadwick \& Anderson, 1995). Since no specific aetiological agent has been isolated, it might well be that the cause of the disease is, indeed, a mucosa-associated organism as these are inherently difficult to culture.

\section{Colon cancer}

The aetiology of colorectal cancer is thought to be bacterial, since germ-free animals have much lower rates of incidence of colon cancer (Rumney et al. 1993). The metabolic end products of certain colonic bacteria have been described as carcinogenic or genotoxic: such products include nitrosamines, fecapentaenes, secondary bile acids, heterocyclic amines, various aglycones, phenolic/indolic compounds, nitrated polycyclic aromatic hydrocarbons, diacylglycerol, some azo compounds and ammonia. Such potentially carcinogenic compounds are often derived from colonic fermentation of amino acids or peptides or by the activities of selected microbial enzymes on pre-carcinogens and xenobiotic compounds that may be ingested in the diet (Goldin, 1986). Table 1 lists bacterial enzymes that generate toxic, genotoxic or carcinogenic products from dietary substrates.

Generally, lactobacilli and bifidobacteria have low (if any) levels of carcinogenic enzyme activity compared with other anaerobic species such as bacteroides, eubacteria and clostridia (Vanderhoof \& Young, 1998). For example, Clostridium perfringens is responsible for the conversion of primary to secondary bile acids in the colon, through the action of 7- $\alpha$-dehydroxylase. The proportion of bacterial strains that possess $7-\alpha$-dehydroxylase activity is higher among the microflora of consumers of a Western-type diet (Watanabe \& Koessel, 1993). Dietary intake studies demonstrate a correlation between high faecal concentrations of secondary bile acids and dietary intake of fat among North Americans and western Europeans (Goldin, 1986). Enzymes such as $\beta$-glucuronidase, azoreductase and nitroreductase can be

Table 1. Bacterial enzymes that generate toxic, genotoxic or carcinogenic products from dietary substrates (from Rowland, 1996)

\begin{tabular}{ll}
\hline Enzyme & Substrate \\
\hline$\beta$-Glycosidase & Plant glycosides, e.g. rutin, franguloside \\
Azoreductase & Azo compounds, e.g. benzidine-based dyes \\
Nitroreductase & Nitro compounds, e.g. dinitrotoluene \\
$\beta$-Glucuronidase & Biliary glucuronides, e.g. benzol(a)pyrene \\
$\mathrm{IQ}$ 'hydratase-dehydrogenase' & IQ \\
Nitrate/nitrite reductase & Nitrate, nitrite
\end{tabular}

IQ, 2-amino-3-methyl-3H-imidazo(4,5-f)quinoline. 
inhibited by a lowering of colonic $\mathrm{pH}$. This may be achieved through fermentation by gut bacteria (Rowland \& Tanaka, 1993). However, care must be taken when describing the metabolic activities or capabilities of groups of micro-organisms, since a high degree of phenotypic heterogeneity exists between different species within the same genera. For example, the probiotic strain of L. rhamnosus possesses azoreductase activity in vitro (Hartemink et al. 2000), whereas other strains have been shown to reduce azoreductase activities in vivo in animal models (Rowland, 1992).

Bacterial $\beta$-glucuronidase and $\beta$-glycosidase appear to have an important role in the production of carcinogens. Many dietary compounds that occur in plants are not carcinogenic. However, bacterial $\beta$-glycosidase has a wide substrate specificity and the ability to hydrolyse many different glycosides with the production of aglycone compounds, which in most cases are carcinogenic (Goldin, 1986). For example, azoxymethane and cycasin are both inactive in their glycone form but become carcinogenic after the action of bacterial $\beta$-glucosidase. Toxic substances are detoxified in the liver by glucuronide formation and subsequently enter the gut in bile; deconjugation in the colon through bacterial $\beta$-glucuronidase activity regenerates the carcinogen (Goldin, 1986). However, in some cases, the action of bacterial glycoside hydrolysis may be beneficial: for example, the isoflavones genistein and daidzein are present predominantly in soyabean and soya food products in the glycone form but demonstrate far greater oestrogenic activity in the aglycone form (Miksicek, 1995). Therefore, it is reasonable to assume that the extent of bacterial glycoside hydrolysis of genistein and daidzein will influence the potential for beneficial physiological effects of isoflavones (Setchell, 1998). Our current research is utilising a molecular approach to speciate the specific gut bacteria involved.

\section{Gastroenteritis}

Gastroenteritis results from the ingestion of foods contaminated with pathogenic microorganisms or their toxins, or both (Zottola \& Smith, 1990). Typical causative agents include shigellae, salmonellae, Yersinia enterocolitica, Campylobacter jejuni, Escherichia coli, Vibrio cholerae and Clostridium perfringens (Isolauri et al. 1999a,b). Pathogens either may colonise and grow within the gastrointestinal tract and then invade host tissue, or may secrete exotoxins contaminating food prior to its ingestion (Zottola \& Smith, 1990). Such enterotoxins disrupt function of the intestinal mucosa, causing nausea, vomiting and diarrhoea (Prescott et al. 1996). The principal human intestinal bacterial pathogens can be characterised according to the virulence factors that enable them to overcome host defences (Table 2).

The gut microflora itself acts as a barrier against invasion by potential pathogens (Isolauri et al. 1999a,b). Bifidobacteria are known to inhibit the growth of various pathogens in vitro. This phenomenon which is due to several mechanisms, can be dubbed the 'Bifidobacterium barrier'. The production of SCFA results in a hostile environment for pathogens such as E. coli, Campylobacter and Salmonella spp. Bifidobacteria also produce antimicrobial agents active against Gram-negative and Gram-positive pathogens (Gibson \& Wang, 1994). In addition, bifidobacteria are able to bind to various cell-surface glycolipids, occupying potential receptor sites for pathogens and it has been reported that they are also able to produce anti-adhesive glycans and proteins, inhibiting the binding of pathogens to their cellular receptors (Umesaki, 1989; Fujiwara et al. 1997). 
Table 2. Summary of pathogens involved in gastroenteritis: their epidemiology, pathogenesis and clinical features

\begin{tabular}{|c|c|c|c|}
\hline Organism & Epidemiology & Pathogenesis & Clinical features \\
\hline Bacillus cereus & $\begin{array}{l}\text { Growth in reheated } \\
\text { fried rice causes } \\
\text { vomiting or } \\
\text { diarrhoea }\end{array}$ & $\begin{array}{l}\text { Enterotoxins } \\
\text { formed in food or } \\
\text { in gut from growth } \\
\text { of } B \text {. cereus }\end{array}$ & $\begin{array}{l}\text { With incubation } \\
\text { period of } 2-8 \mathrm{~h} \\
\text { mainly vomiting; } \\
\text { with incubation } \\
\text { period of } 8-16 \mathrm{~h} \text {, } \\
\text { usually diarrhoea }\end{array}$ \\
\hline $\begin{array}{l}\text { Clostridium } \\
\text { perfringens }\end{array}$ & $\begin{array}{l}\text { Grows in reheated } \\
\text { meat dishes. Large } \\
\text { numbers ingested }\end{array}$ & $\begin{array}{l}\text { Enterotoxin } \\
\text { produced during } \\
\text { sporulation in the } \\
\text { gut, causes } \\
\text { hypersecretion }\end{array}$ & $\begin{array}{l}\text { Abrupt onset of } \\
\text { profuse diarrhoea; } \\
\text { vomiting } \\
\text { occasionally }\end{array}$ \\
\hline $\begin{array}{l}\text { Clostridium } \\
\text { botulinum }\end{array}$ & $\begin{array}{l}\text { Grows in anaerobic } \\
\text { foods and produces } \\
\text { toxin }\end{array}$ & $\begin{array}{l}\text { Toxin absorbed } \\
\text { from gut blocks } \\
\text { acetylcholine at } \\
\text { neuromuscular } \\
\text { junction }\end{array}$ & $\begin{array}{l}\text { Diplopia, } \\
\text { dysphagia, } \\
\text { dysphonia, } \\
\text { respiratory } \\
\text { embarrassment }\end{array}$ \\
\hline Escherichia coli & $\begin{array}{l}\text { Grows in gut and } \\
\text { produces toxin; } \\
\text { may also invade } \\
\text { superficial } \\
\text { epithelium }\end{array}$ & $\begin{array}{l}\text { Toxin causes } \\
\text { hypersecretion of } \\
\text { chloride and water } \\
\text { in small intestine }\end{array}$ & $\begin{array}{l}\text { Usually abrupt } \\
\text { onset of diarrhoea; } \\
\text { vomiting rare }\end{array}$ \\
\hline Vibrio cholerae & $\begin{array}{l}\text { Grows in gut and } \\
\text { produces toxin }\end{array}$ & $\begin{array}{l}\text { Toxin causes } \\
\text { hypersecretion of } \\
\text { chloride and water } \\
\text { in small intestine; } \\
\text { infective dose }>10^{7} \\
\text { vibrios }\end{array}$ & $\begin{array}{l}\text { Abrupt onset of } \\
\text { liquid diarrhoea in } \\
\text { endemic area }\end{array}$ \\
\hline Shigella spp. & $\begin{array}{l}\text { Grows in } \\
\text { superficial gut } \\
\text { epithelium }\end{array}$ & $\begin{array}{l}\text { Organism invades } \\
\text { epithelial cells; } \\
\text { blood, mucus and } \\
\text { PMN in stools; } \\
\text { infective dose } \\
<10^{3} \text { organisms }\end{array}$ & $\begin{array}{l}\text { Abrupt onset of } \\
\text { diarrhoea, often } \\
\text { with blood or pus } \\
\text { in stools, cramps, } \\
\text { tenesmus and } \\
\text { lethargy }\end{array}$ \\
\hline Salmonella spp. & $\begin{array}{l}\text { Grows in gut, does } \\
\text { not produce toxin }\end{array}$ & $\begin{array}{l}\text { Superficial } \\
\text { infection in the gut, } \\
\text { little invasion; } \\
\text { infective dose }>10^{5} \\
\text { organisms }\end{array}$ & $\begin{array}{l}\text { Gradual or abrupt } \\
\text { onset of diarrhoea } \\
\text { and low-grade } \\
\text { fever }\end{array}$ \\
\hline $\begin{array}{l}\text { Clostridium } \\
\text { difficile }\end{array}$ & $\begin{array}{l}\text { Antibiotic-associated } \\
\text { colitis }\end{array}$ & $\begin{array}{l}\text { Toxin causes } \\
\text { epithelial necrosis } \\
\text { in colon, } \\
\text { pseudomembranous } \\
\text { colitis }\end{array}$ & $\begin{array}{l}\text { Especially after } \\
\text { abdominal surgery, } \\
\text { abrupt bloodly } \\
\text { diarrhoea and } \\
\text { fever }\end{array}$ \\
\hline $\begin{array}{l}\text { Campylobacter } \\
\text { jejuni }\end{array}$ & $\begin{array}{l}\text { Infection via oral } \\
\text { route from food, } \\
\text { pets; organism } \\
\text { grows in small } \\
\text { intestine }\end{array}$ & $\begin{array}{l}\text { Invasion of mucous } \\
\text { membrane; toxin } \\
\text { production } \\
\text { uncertain }\end{array}$ & $\begin{array}{l}\text { Fever, diarrhoea; } \\
\text { PMN and fresh } \\
\text { blood in stool, esp. } \\
\text { in children }\end{array}$ \\
\hline $\begin{array}{l}\text { Yersinia } \\
\text { enterocolitica }\end{array}$ & $\begin{array}{l}\text { Faecal-oral } \\
\text { transmission; } \\
\text { foodborne; } \\
\text { animals infected }\end{array}$ & $\begin{array}{l}\text { Gastroenteritis or } \\
\text { mesenteric adenitis; } \\
\text { occasional } \\
\text { bacteraemia; toxin } \\
\text { produced } \\
\text { occasionally }\end{array}$ & $\begin{array}{l}\text { Severe abdominal } \\
\text { pain, diarrhoea, } \\
\text { fever; PMN and } \\
\text { blood in stools; } \\
\text { polyarthritis, } \\
\text { erythema nodosum, } \\
\text { esp. in children }\end{array}$ \\
\hline
\end{tabular}

PMN, polymorphonuclear leucocytes.

\section{Neonatal necrotising enterocolitis}

Neonatal necrotising enterocolitis (NEC) is a world-wide problem probably accounting for at least $10 \%$ of all deaths among infants of very low birth weight; $90 \%$ of NEC patients are premature infants in neonatal intensive care units. Intestinal mucosal injury, bacterial coloni- 
sation, rapid increase in the gas volume of gastric aspirate and formula feeding are thought to be factors in the development of NEC (Butel et al. 1998). Hence, it is rare in infants whose diet includes breast milk, being six to ten times more common in exclusively formula-fed infants (Dai \& Walker, 1998).

The pathogenesis of disease implies delayed gut colonisation with a limited number of bacterial species, which tend to be virulent (Dai \& Walker, 1998). Although colonisation with potential pathogens appears to be a prerequisite for development of NEC, no specific bacteria have been associated with the condition (Peter et al. 1999). Animal models of NEC have implicated Clostridium spp. Studies carried out by Butel et al. (1998) examined the possible role of $C$. butyricum as the pathological agent of NEC. Germ-free quails were used as experimental models and were fed on a semi-synthetic diet containing $8 \%$ lactose. NEC-like lesions were observed in quails associated with $C$. butyricum and in quails associated with the faecal microflora, taken from a NEC patient, containing three different clostridia (C. butyricum, $C$. perfringens and $C$. difficile). Conversely, no lesions were found in germ-free quails associated with Bifidobacterium infantis-longum or in quails associated with the faecal microflora, containing bifidobacteria and no clostridia, taken from the healthy neonate twin of the NEC patient. Further studies have shown that bifidobacteria may have a protective role against NEC, to the extent that inoculation of premature babies with $B$. breve stabilized the gut microflora, increased weight gain in infants of very low birth weight and resulted in a reduction in gastric aspirated air volume (Kitajima et al. 1997).

However, no clear link has been made between specific bacterial groups or species and the aetiology of NEC. This may be due to the treatment of patients with antibiotics or to some role of non-culturable bacteria in the onset or maintenance of NEC. Clearly, there is a need to characterise both the culturable and non-culturable moieties of the NEC gut microflora.

\section{Pseudomembranous colitis}

One of the few gastrointestinal disorders that has a clearly defined aetiology is pseudomembranous colitis. Also recognised as antibiotic-associated colitis, it is almost exclusively found in association with exposure to antimicrobials such as clindamycin, ampicillin and cephalosporins (Gibson \& Macfarlane, 1994). The causative agent is Clostridium difficile, which is usually suppressed by the normal gut flora. However, antibiotic use compromises this 'barrier effect', thereby allowing proliferation of $C$. difficile and its elaboration of two powerful toxins. These cause the accumulation of a pseudomembrane composed of fibrin and mucin. In the severest of cases, this has the ability to occlude the gut lumen, thus causing dysfunction. The condition is treated with anionic resins (to bind the toxins) and vancomycin (to inhibit $C$. difficile).

\section{Pneumatosis cystoides intestinalis}

Gas is an important end product of gut microbial activities, with a typical adult producing in the region of $4 \mathrm{l} / \mathrm{d}$. Mainly, this is composed of $\mathrm{H}_{2}, \mathrm{CO}_{2}$ and $\mathrm{CH}_{4} \cdot \mathrm{H}_{2}$ is of physiological relevance as it acts as an 'electron sink', thereby generating extra energy from colonic fermentation. Predictions of the amount of $\mathrm{H}_{2}$ that should theoretically be formed from anaerobic carbohydrate metabolism in the gut vastly exceed the levels actually produced (Levitt et al. 1995). This is because other micro-organisms become involved in the uptake of hydrogen. Principally, these are sulfate-reducing, methanogenic and acetogenic bacteria, respectively producing $\mathrm{H}_{2} \mathrm{~S}$, $\mathrm{CH}_{4}$ and acetate (Gibson, 1990; Levitt et al. 1995). In the condition pneumatosis cystoides 
intestinalis, there appears to be a defect in the micro-organisms responsible for $\mathrm{H}_{2}$ disposal, with sufferers producing five to ten times more gas (mainly $\mathrm{H}_{2}$ ) than is usual (Christl et al. 1993). It is unclear why persons with pneumatosis cystoides intestinalis are lacking sulfate reducers, methanogens or acetogens; attempts to implant these species have, hitherto, been unsuccessful.

\section{Dietary augmentation of microbial health benefits: probiotics, prebiotics, synbiotics}

Recognition of the beneficial aspects of specific commensal micro-organisms has encouraged modulation of the human gut microbiota towards a more beneficial composition and metabolism, through probiotics, prebiotics and synbiotics (Fuller \& Gibson, 1997; Collins \& Gibson, 1999; Gibson et al. 2000). The concept of gut modulation for improved host health has a history dating back at least to the beginning of the twentieth century, but it is only recently that sound scientific rationales have been proposed and investigated. Three strategies have emerged: these are (1) the improvement of the gut microflora through addition of exogenous micro-organisms (i.e. probiotics); (2) selective advancement of the growth and activity of beneficial species indigenous to the host gastrointestinal tract (i.e. prebiotics); (3) synbiotics, which are combinations of both (Gibson \& Roberfroid, 1995).

\section{Probiotics}

Probiotics are live microbial food supplements which have a beneficial effect on the intestinal balance of the host animal (Fuller, 1989). Much recent effort has concentrated on identifying probiotic bacteria and characterising their beneficial credentials. It is generally considered that probiotics must possess certain properties; they must survive passage through the upper regions of the gastrointestinal tract and persist in the colon; there must be no adverse response to the bacteria, their components or metabolic end products; they should be antagonistic to mutagenic or pathogenic organisms in the gut and must be genetically stable; for successful introduction of the probiotic concept into the food market, chosen micro-organisms must be amenable to industrial processes and remain viable in the final food product (Ziemer \& Gibson, 1998; Collins \& Gibson, 1999). Advances in the genetics of probiotic strains (usually Lactobacillus spp. or yeasts) have enabled the determination of some of the mechanisms involved in probiotic function, such as production of antimicrobials, adhesion to the mucosa and the metabolic pathways responsible for SCFA production. This raises the possibility of modifying existing strains to increase survival and efficacy in the human gastrointestinal tract. However, there is a lack of understanding concerning which of these probiotic mechanisms are responsible for specific health outcomes in vivo.

The health benefits associated with probiotic ingestion are listed in Table 3. Care must be taken when considering many of the suggested health-promoting capabilities, since much of the supportive scientific data have been generated from studies in vitro or small-scale human volunteer trials (Ziemer \& Gibson, 1998). There is a clear need not only for large-scale human volunteer studies to support such claims but also for fundamental research into the mechanisms by which probiotics affect human health. In this respect, the correlation of probiotic activities, such as anti-pathogenicity, with specific health outcomes in vivo will allow rational choice of probiotic strain and targeting of subpopulations at particular risk of gastrointestinal complaints (e.g. the aged). Thus, directed probiotic application may be achieved, enabling specific health claims to be investigated in clearly defined clinical trials. 
Table 3. Probiotic bacteria and their reported health benefits in clinical studies (from Lee \& Salminen, 1995 and Ziemer \& Gibson, 1998)

\begin{tabular}{|c|c|}
\hline Reported effects & Probiotic species \\
\hline Modulation of immune system & $\begin{array}{l}\text { Lactobacillus acidophilus, L. casei, L. plantarum, L. delbrueckii, L. } \\
\text { rhamnosus }\end{array}$ \\
\hline $\begin{array}{l}\text { Balancing of gut microbiota } \\
\text { Reduced faecal enzyme activities } \\
\text { (enzymes involved in activation } \\
\text { of carcinogens) }\end{array}$ & $\begin{array}{l}\text { L. acidophilus, L. casei, Bifidobacterium bifidum } \\
\text { L. acidophilus, L. casei, L. gasseri, L. delbrueckii }\end{array}$ \\
\hline Antitumour & $\begin{array}{l}\text { L. acidophilus, L. casei, L. gasseri, } L \text {. delbrueckii, L. plantarum, } B \text {. } \\
\text { infantis, } B \text {. adolescentis, B. bifidum, B. longum }\end{array}$ \\
\hline Prevention of traveller's diarrhoea & $\begin{array}{l}\text { Saccharomyces spp., mixture of } L \text {. acidophilus, } B \text {. bifidum, } \\
\text { Streptococcus thermophilus, } L \text {. bulgaricus }\end{array}$ \\
\hline $\begin{array}{l}\text { Prevention of rotavirus diarrhoea } \\
\text { Prevention of } C \text {. difficile diarrhoea } \\
\text { Prevention of other diarrhoea }\end{array}$ & $\begin{array}{l}\text { L. rhamnosus, B. bifidum } \\
\text { L. rhamnosus, S. spp. } \\
\text { L. acidophilus, L. rhamnosus, B. bifidum }\end{array}$ \\
\hline
\end{tabular}

Probiotics and the immune system Some of the most convincing research on the efficacy of probiotics comes from the area of food intolerance and allergy: this includes in particular, intolerance to cows' milk protein and lactose and the ability of probiotics to aid digestion of these components (Sanders, 1993). Members of the gut microbiota, occupying a juxtamucosal niche in the intestine, have been shown to modulate specific immune responses in gut-associated lymphoid tissue. Sudo et al. (1997) demonstrated that the gut microflora contributes towards generation of T-helper cells which induce oral tolerance, and this has led to the possibility of using probiotic strains as therapeutic agents in hypersensitive disorders. Lactobacilli and bifidobacteria have a natural association with the gut mucosa and are able to promote normalisation of the increased intestinal permeability that occurs during exposure to food allergens (Isolauri et al. 1999a). In addition, probiotic strains are capable of reducing the production of interleukin (IL)-4 during casein fermentation, excess production of IL-4 being one of the key features of atopic patients and responsible for initial sensitisation (Sütas et al. 1996). Human studies have recently been conducted on the ability of probiotics to prevent development of an immunological memory capable of producing an abnormal response to cows' milk at an early age (Majamaa \& Isolauri, 1997). In a randomised double-blind study in infants with early-onset atopic eczema and sensitisation to basic foods, hydrolysed whey formula fortified with Lactobacillus GG $\left(5 \times 10^{8} \mathrm{CFU} / \mathrm{g}\right.$ formula) was consumed by the treatment group ( $n$ 13) for 1 month. A significant decrease in faecal $\alpha_{1}$-antitrypsin $(P=0.03)$ and tumour necrosis factor- $\alpha(P=0.003)$ compared with the control group was observed. As $\alpha_{1}$-antitrypsin and tumour necrosis factor- $\alpha$ are both markers for intestinal inflammation, these results suggest that probiotics not only promote endogenous barrier mechanisms but also are able to alleviate intestinal inflammation often seen in food allergy. Table 4 outlines how probiotics are able to modulate allergic inflammation.

Table 4. Modulation of the immune system by probiotic micro-organisms (from Isolauri et al. 1999a,b)

- Altering the immunogenicity of allergens via proteolytic activity

- Normalising the composition of the intestinal microbiota

- Reducing the secretion of inflammatory mediators in the gut

- Reversing increased intestinal permeability

- Reversing enhanced absorption of macromolecules

- Enhancing the mucosal immunoglobulin A response to enteral antigens

- Modifying the systemic changes related to allergic inflammation

- Alleviating the clinical symptoms of food allergy 
Probiotics and antitumour properties Lyophilised cultures of probiotic strains, Bifidobacterium longum in particular, have been shown to suppress the development of aberrant crypt foci (ACF) in rats given azoxymethane-induced colon cancer (Rafter, 1995; Reddy, 1998). However, most animal studies have been carried out with specifically bred strains of rodents and the question of whether these results can be extrapolated to humans is still unclear. Of the human feeding studies that have been carried out, treatment groups tend to be small $(n<30)$ and of short duration. Although these studies do show a reduction in faecal enzymes that may be associated with the formation of carcinogens, it is still unclear whether these would affect long-term cancer rates. Reports published to date are not consistent in finding reductions in the same enzymes (Goldin \& Gorbach, 1984; Lidbeck et al. 1992; Hayatsu \& Hayatsu, 1993).

Probiotics and diarrhoea Ingestion of probiotic strains as prophylactic agents against diarrhoea is based on the ecological principle of competitive exclusion. Effectiveness depends on the strain of bacteria, its suitability to an individual and the ability to displace pathogens (O'Sullivan \& Kullen, 1998). Such probiotics have potential for the prevention and treatment of gastrointestinal infections, one specific example being the application of Bifidobacterium bifidum and Streptococcus thermophilus in the case of infant viral diarrhoea (Saavedra et al. 1994). The authors conducted a double-blind, placebo-controlled trial in hospitalised infants who were randomised to receive a standard infant formula or the same supplemented with a probiotic. Over a 17-month follow-up, $31 \%$ of the patients given the standard infant formula developed diarrhoea, compared with only $7 \%$ of those receiving the probiotic supplement; the prevalence of rotavirus shedding was significantly lower in those receiving the probiotic. Preparations of prophylaxis for traveller's diarrhoea have been studied using Lactobacillus acidophilus, Bifidobacterium bifidum, Lactobacillus bulgaricus and Streptococcus thermophilus, but the results have been conflicting. This may be due to variability in species and delivery vehicle used, the dosage, and differences in travel destinations. However, there is evidence that certain strains of lactic acid bacteria provide protection against traveller's diarrhoea. Future studies need to provide dose-response data and details on the aetiological agents causing diarrhoea in different destinations. A recent review (Buddington \& Weiher, 1999) has suggested the use of probiotics in combination with oral rehydration therapy and antibiotics, to prevent antibiotic-associated diarrhoea. The depletion of fluids and electrolytes caused by diarrhoea is replenished by oral electrolyte solutions, but these do not address disturbances to the structure and functions of the gastrointestinal tract or to the resident microflora. Although recovery by the gut microflora occurs over time, species with shorter generation times recover more quickly. Such changes in the colonic environment may lead to the proliferation of potential pathogens such as Clostridium difficile (Wilson, 1993). This area of research offers potential benefits, particularly in infants and the elderly who are at greater risk of complications from diarrhoea (Buddington \& Weiher, 1999).

Scientific approach to establishing the functional benefits of probiotic bacteria Despite much research into the health benefits of probiotics, progress has been hampered by a variety of factors. Individual studies provide insight into a specific probiotic strain; however, as bacteria have a very heterogeneous nature and differ according to genera, species and strain, it is difficult to make general conclusions about probiotics as a whole. In addition, the variety of health benefits of probiotics means that, at present, a diversity of end points is being studied in clinical trials. It is, therefore, problematic to reach a scientific consensus on the effect of probiotics on health outcome (Sanders, 1998); in each area of potential health benefits there is a need for current research to focus on well-controlled human trials. 
Limitations of the probiotic approach The major limitations of the probiotic approach are survivability in storage and suppression in the gastrointestinal tract. Because of the climax microbial ecosystem present in the human colon, for a particular bacterial species to have any major effect on the ecology of the colon it must be present in numbers at least as high as 7-8 $\log _{10} \mathrm{CFU} / \mathrm{ml}$ lumen contents (Ducluzeau \& Bensaada, 1982). Similarly, repeated dosing is needed to maintain biologically significant numbers of probiotics (Korpela \& Saxelin, 1999). Clearly, a distinction must be drawn between strains that attain high stable populations in the gut microflora through daily oral dosing and indigenous members of the microbiota. Kullen et al. (1997) found that, when daily ingestion of a probiotic preparation containing a Bifidobacterium spp. strain ceased, the strain was detectable in faeces for only up to 8d (using RFLP analysis of $16 \mathrm{~S}$ rDNA). Such observations on colonisation resistance imposed by the gut microflora on ingested micro-organisms (probiotic and pathogen alike) have led scientific investigations into maximising persistence of probiotics in the human colon. Construction (by genetic engineering) or selection of probiotic strains with adhesion sites to the human colonic epithelium is one way of increasing in vivo survivability. However, little is known about which strains adhere to the human colonic epithelium, as bacterial adhesion has not been demonstrated in situ. Similarly, there is much concern over the prospects of probiotic strains genetically modified to contain adhesion sites for the epithelium of the gut mucosa, as such genes may find their way into pathogenic or potentially pathogenic members of their gut microflora in vivo.

\section{Prebiotics}

Prebiotics are non-viable food components (usually oligosaccharides) which evade digestion by mammalian enzymes in the upper regions of the gastrointestinal tract, reach the colon in an intact state and are hydrolysed by beneficial members of the indigenous microbiota (Gibson \& Roberfroid, 1995). Selective fermentation of prebiotics by such micro-organisms must result in a healthier composition of the gut microflora and induce lumenal or systemic effects, beneficial to the host (Gibson \& Roberfroid, 1995; Gibson \& McCartney, 1998). The ideal and most effective prebiotic would also be able to reduce or suppress numbers and activities of known pathogens. Oligosaccharides that have been proposed as prebiotics include lactulose, galactooligosaccharides, fructo-oligosaccharides (FOS), malto-oligosaccharides, xylo-oligosaccharides and soyabean oligosaccharides. The prebiotic potential stems from their selective fermentation by Bifidobacterium spp. and, to a lesser extent, by Lactobacillus spp. in the colonic microflora. The inulin type $\beta(2-1)$ fructans have been thoroughly investigated and confirmed as prebiotics in human volunteer trials (Fooks et al. 1999). The prebiotic effects of other oligosaccharides, such as galacto-oligosaccharides and soyabean oligosaccharides, still require further research, particularly in humans (Grizard \& Barthomeuf, 1999). There are also few comparative data on the relative efficiencies of these molecules or on their selectivity at a species (or even genus) level. It has been suggested that the importance of demonstrating selectivity of bifidobacteria, lactobacilli or both is what determines the classification of a prebiotic. Thus, it is insufficient to demonstrate metabolism of these molecules in pure culture without support by mixed culture work, preferably in human subjects (Gibson et al. 2000). In this respect, what seems to be a limiting factor in undertaking extensive research and eventually large clinical trials is laborious microbial plate-counting techniques. Currently, studies are under way to develop this field using validated quantitative techniques, such as $16 \mathrm{~S}$ rRNA probes, to assess the microflora at the genus level (Ames et al. 1999; Gibson et al. 2000; 
K Tuohy, S Kolida, A Lustenberger and GR Gibson, unpublished results; K Tuohy, CJ Ziemer and GR Gibson, unpublished results). At present, there is more scientific information to support the health benefits of probiotic consumption than for those of prebiotics, where clinical trials are lacking. However, this situation is rapidly being redressed.

Prebiotics and cancer The use of prebiotics in cancer prevention is still mainly at the animal trial stage (Van Loo et al. 1999). Significant reductions in colonic ACF have been observed in rodents treated with azoxymethane and given the prebiotic inulin at $50 \mathrm{~g} / \mathrm{kg}$ diet (Rowland et al. 1998). Interestingly, a potentiating effect was seen in reduction of ACF through the addition of bifidobacteria to the inulin (Gallaher et al. 1996). Currently, data from research with rodents and the administration of inulin-type fructans warrant human nutrition trials. Buddington et al. (1996) indicated that consumption of FOS $(4 \mathrm{~g} / \mathrm{d})$ in human subjects produced an increase in bifidobacteria along with a decrease in $\beta$-glucuronidase and glycholic acid hydroxylase by $75 \%$ and $90 \%$ respectively. Both of these carcinogen-producing enzymes increased after interruption of the FOS supplementation. The situation appears to be different with galacto-oligosaccharides. A recent human trial was carried out by Alles et al. (1999). Forty subjects were divided into three groups; each participant consumed a controlled experimental diet for 3 weeks followed by an intervention of $0,7.5$ or $15 \mathrm{~g}$ transgalacto-oligosaccharides for a further 3 weeks. Although the authors found a high fermentability $(100 \%)$ of the transgalacto-oligosaccharides there were no significant increases in bifidobacteria or SCFA, nor were there any significant decreases in bile acids, ammonia, indoles or skatoles, or faecal $\mathrm{pH}$.

Lactulose is a synthetic disaccharide commonly used as a laxative; however, at sublaxative doses, lactulose is bifidogenic (Modler, 1994; K Tuohy, CJ Ziemer and GR Gibson, unpublished results). Rowland et al. (1996) fed human-microflora-associated (HFA) rats with lactulose at $3 \%(\mathrm{w} / \mathrm{v})$. After 4 weeks on the diet the rats were given the carcinogen 1,2dimethylhydrazine dihydrochloride $(\mathrm{DMH}, 15 \mathrm{mg} / \mathrm{kg})$. After addition of $\mathrm{DMH}$, the rats were killed and examined for cellular DNA damage through the Comet assay. The authors showed that rats given lactulose had significantly $(P<0.05)$ less DNA damage than those given a control diet which contained just sucrose. In a human trial (Terada et al. 1992) eight volunteers who had been given lactulose $(3 \mathrm{~g} / \mathrm{d})$ showed a decrease in enzyme activities associated with carcinogen production (e.g. $\beta$-glucuronidase, nitroreductase and azoreductase). The bifidogenic nature of lactulose has been confirmed using both traditional microbiological culture techniques and molecular probes for bacterial enumeration in a double-blind placebo-controlled study ( $\mathrm{K}$ Tuohy, CJ Ziemer and GR Gibson, unpublished results).

Research is currently under way to identify the strains of bacteria involved in the metabolism of known dietary anticarcinogens such as phytic acid, present in cereal grains, legumes and vegetables, and isoflavones, present mainly in soyabeans. Identification of the bacteria involved may allow the use of prebiotics that prevent breakdown of these dietary anticarcinogens by appropriately diverting bacterial metabolism.

Potential for functional enhancement of oligosaccharides and prebiotics The current status of prebiotics is that they alter the gut flora composition towards a purportedly healthier community (e.g. one dominated by bifidobacteria). However, there are many other desirable attributes that can be encompassed into the approach of enhanced prebiotics. As the approach is to use non-viable food ingredients, the biotechnology involved is more rational than that for probiotics. Enhanced prebiotic properties may include the following aspects: (1) highly selective fermentation; (2) increased persistence through the colon; (3) anti-adhesive prebiotics; (4) attenuation of virulence of pathogens; (5) reduction of gas production. 
To ensure that a prebiotic is selectively fermented only by bifidobacteria and lactobacilli, biotechnological methods of manufacture would allow the development of highly selective molecules. The two methods for the manufacture of enhanced prebiotics are (a) synthesis of oligosaccharides from simple sugars and (b) controlled hydrolysis of polysaccharides such as starch, pectin and cellulose (Gibson et al. 2000). Future research will need to examine the glycosidase profiles of beneficial species of bacteria and carbohydrate transport mechanisms operating in these species.

As the majority of colon cancers occur in the distal colon/rectum (Bingham, 1996), a prebiotic which persists in this area is the focus of current and future research. Similarly, UC is a disease of the distal colon, at least in the early stages. Techniques are being developed to manufacture prebiotics that resist hydrolysis in the proximal colon and allow selective fermentation throughout the length of the hindgut. However, given the saccharolytic nature of the proximal colon, this may be difficult to achieve. Our current research, with a validated model of the human gut (see later), suggests that increased molecular weight may enhance persistence. For example, long-chain inulin may exert an extended prebiotic effect in distal colonic regions when compared with the lower molecular weight FOS. In addition, microbial fructans such as laevan have a huge molecular weight that is considerably greater than that of long-chain inulin which has a degree of polymerisation of 2-60. It is reasonable to assume that such a polysaccharide would take longer to be metabolised in the colon, thereby increasing the chances of persistence towards distal areas.

A prebiotic with anti-adhesive properties against pathogenic bacteria would confer major functionality with respect to altering gut pathogenesis. Many intestinal pathogens use carbohydrate-binding proteins to attach to cells and initiate disease (Table 5). The first line of defence consists of receptor oligosaccharides in the mucous layer that lines exposed epithelial cells in the gastrointestinal tract (Zopf \& Roth, 1996). Knowledge of these receptor sites has relevance for biologically enhanced prebiotics. Soluble oligosaccharides may prevent bacterial attachment and dislodge bacteria attached to epithelial cells. In breast milk, several oligosaccharides have been identified that protect infants from many infectious agents (Carlson, 1985). In the past few decades, carbohydrate-binding proteins used by pathogens to recognise and adhere to cell surfaces have been described (Ofek \& Doyle, 1994). The pathogen proteinreceptor sites have strict requirements for their oligosaccharide ligands, usually consisting of three, four or five monosaccharides. This specificity is probably one of the main factors that determines not only which host species a pathogen can colonise but also the site of initial colonisation (Zopf \& Roth, 1996). Pathogen binding is the first step in the infection process and oligosaccharides may act as 'blocking factors', by dislodging pathogens or preventing their adhesion of attachment site on mucosal cells by steric hindrance. Prebiotics incorporating these

Table 5. Examples of carbohydrate pathogen receptors (from Gibson et al. 2000)

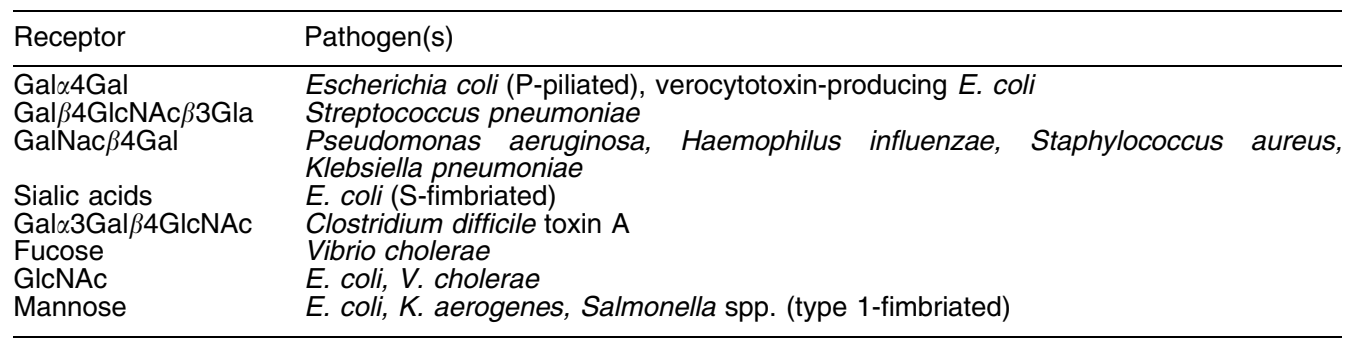


receptor monosaccharides or oligosaccharide sequences would act as 'decoy' molecules for potential pathogenic bacteria.

The use of prebiotics to attenuate virulence of certain food-borne pathogens has also been a recent development in the area of prebiotics. For example, the pathogenicity of Listeria monocytogenes is repressed in the presence of the plant-derived carbohydrate cellobiose (Park \& Kroll, 1993). This micro-organism is avirulent in its natural habitat of soil, where it is exposed to rotting vegetation and therefore the cellulose oliomer cellobiose. In the human body the absence of free cellobiose may allow virulence to be expressed, opening up the possibility of appropriate food supplementation.

Fermentation of prebiotics may lead to production of excess gas, which results in flatulence, bloating and abdominal discomfort (Grizard \& Barthomeuf, 1999). To prevent such undesirable symptoms, partial controlled hydrolysis of natural high molecular weight fermentable carbohydrates such as pectins or guar gum, or processing of inulin to produce longchain fructans (De Leenheer, 1996), may result in less gas production as they are fermented much more slowly in the colon (Grizard \& Barthomeuf, 1999).

It is known that lactic acid bacteria ferment substrates without producing gas. Immediately, this raises the question as to why there is an increase in gas production on the administration of certain prebiotics, as these compounds are supposedly selectively fermented by non-gasproducing genera such as bifidobacteria. This apparent anomaly serves to highlight the way that the fermentation pathways in the colon are interrelated.

\section{Synbiotics}

The synbiotic concept combines efficacious probiotic strains with specific prebiotic compounds in a single product. The aim is, therefore, to improve probiotic survival during passage through the upper intestinal tract and to produce a more efficient implantation in the colonic microflora, together with a stimulating effect on the growth or activities (or both) of both the probiotic and certain indigenous strains (Roberfroid, 1998).

A problem in conducting clinical trials with synbiotics is in determining which component of the synbiotic has any effect. For example, Bouhnik et al. (1996) assessed, in healthy human subjects, the effects of ingestion of Bifidobacterium spp. in fermented milk with or without inulin $(18 \mathrm{~g} / \mathrm{d})$ on faecal bifidobacterial numbers. The authors concluded that administration of Bifidobacterium spp. significantly increased faecal bifidobacteria but that the addition of inulin had no extra enhancing effect. However, the volunteers tested already had high counts of bifidobacteria in their faeces at the start of the study $\left(10^{7 \cdot 7}-10^{9} \mathrm{CFU} / \mathrm{g}\right.$ faeces $)$ and it is likely that stimulation of growth depends very much on initial faecal counts. At 2 weeks after the consumption of the fermented milk, the volunteers who had taken the synbiotic product still had significantly $(P<0 \cdot 01)$ higher numbers of bifidobacteria than those receiving the probiotic alone. This could be due either to a better implantation of the probiotic or simply to a prebiotic effect only on indigenous bifidobacteria.

The synbiotic concept has been tested in rodents treated with the colonic carcinogen azoxymethane (Rowland et al. 1998). The rodent diets were treated with either $5 \%(\mathrm{w} / \mathrm{v})$ chicory inulin, with Bifidobacterium longum $25\left(7-10^{8} \mathrm{CFU} / \mathrm{g}\right)$, or both. For the inulin and Bifidobacterium longum diets, there was a reduction in the total number of ACF $(-29 \%$ and $-21 \%$ respectively) and in the number of foci with one to three aberrant crypts $(-41 \%$ and $-26 \%$ respectively), but not in the number of larger foci (four or more aberrant crypts), after 12 weeks. However, in rodents treated with the synbiotic there was a decrease in total numbers 
of ACF by $74 \%$, in the number of foci with one to three aberrant crypts by $80 \%$ and the number of large foci by $58 \%$. These data support the synergistic activity of prebiotic and probiotic moieties in the synbiotic approach. However, such observations need further investigation and, as with prebiotics and probiotics, synbiotics require efficacious human feeding trials.

It may be that the market niche for the pro-, pre- and synbiotics concept lies in augmentation of the gut microflora of specific groups of individuals possessing an abnormal gut microflora, such as the aged, pre-term infants, patients with persistent gastrointestinal complaints or those who have received prolonged antibiotic therapy (Vanderhoof \& Young, 1998; Collins \& Gibson, 1999). Kleessen et al. (1997) showed that the trend whereby Bifidobacterium spp. populations in the gut microflora of the elderly decrease may be reversed by consumption of inulin (a prebiotic). Similarly, early administration of B. breve to preterm infants is associated with fewer gastrointestinal abnormalities, better weight gain and stabilisation of the gut microflora (Kitajima et al. 1997).

In summary, the basic concepts of pre- and probiotics have, in recent years, become more refined and targeted at specific health outcomes. Understanding the mechanisms of action of probiotics, prebiotics and synbiotics against gastrointestinal disorders and infection has moved this area of research beyond the simple aim of improving general gastrointestinal health to a more specific target of action or outcome, by modulation of the gut microflora.

\section{In vitro and in vivo models of the gut}

To enable us to ask specific questions about the human gut microflora, in vitro and in vivo models of the human gut have been developed (Gibson et al. 1988; Rumney \& Rowland, 1992; Conway, 1995).

\section{In vitro models}

In vitro models generally employ anaerobic chemostats of varying degrees of complexity or short-term batch cultures of human faeces or lumen samples extracted from animals. They allow generation of data on the effect of specific biotic and abiotic environmental parameters on the gut microflora, which may otherwise be unavailable owing to the inaccessibility of the target environment in the gastrointestinal tract or for ethical reasons.

Simple batch cultures of human faeces have been used for initial studies into fermentative capabilities of the human faecal microflora against specific compounds such as dietary fibre, starches and prebiotics (Wang \& Gibson, 1993; Barry et al. 1995; Edwards et al. 1996). Batch culture allows determination of the fermentability of various substrates during short periods (generally less than $24 \mathrm{~h}$ ). However, because of decreasing substrate concentrations and increased acid and secondary metabolite production by the microflora, the composition in batch cultures changes over time. The use of $\mathrm{pH}$-controlled faecal batch cultures may allow more comparative observations to be made on the fermentability of different carbohydrates and can be used as a first-stage screening process for comparative determination of efficacy and effective prebiotic doses. Continuous or semi-continuous flow systems, on the other hand, replicate the ecological conditions of the human gut to a much greater degree. Continuous inflow of growth media, and outflow of biomass, enable a diverse microflora to be maintained in a steady state (Rumney \& Rowland, 1992). Models of the human gut of varying degrees of complexity have now been developed (Miller \& Wolin, 1981; Allison et al. 1989; Bearne et al. 1990; Molly et al. 1994; Minekus \& Havenaar, 1996; Macfarlane et al. 1998). Such models 
maintain a microflora similar in many ways to that of the human gut in gross species composition and activities. Macfarlane GT et al. (1998) validated a three-stage continuous-flow system of the human gut microflora against the colonic contents of sudden-death victims. Species composition and population levels correlated well with the in vivo samples. Such models have been used to study a range of ecological phenomena, including fermentation studies of both dietary and endogenous substrates, DNA transfer studies between members of the microflora and establishing the prebiotic efficacy of a range of carbohydrates (Freter et al. 1983; Gibson et al. 1988; Gibson \& Wang, 1994; Macfarlane S et al. 1998; Michel et al. 1998; Tuohy, 2000). Attempts have also been made to simulate certain gastrointestinal disease states using in vitro systems. For example, Coutts et al. (1987) used a single-vessel continuous-flow system to reproduce the gastric microflora of a hypochlorhydric patient. However, care must be taken when extrapolating information gained from such studies to the human situation: complex in vitro models may not simulate animal-associated parameters, which have an important role in the microbial ecology of the gut. In this context, endogenous substrates, secretions of the digestive and immune systems and microhabitats provided by both the mucus layer covering the mucosa and the mucosa itself, are not easily reproduced in vitro.

\section{In vivo models}

Gnotobiotic and germ-free animals have been employed as in vivo models of the human gastrointestinal ecosystem for some years. Gnotobiotic technology provides a useful tool for studying interactions between specific members of the human gut microflora, such as the role played by specific bacteria in colonisation resistance to pathogens, bacterial virulence, metabolism of dietary constituents or xenobiotic compounds (Rumney \& Rowland, 1992). Conventional animals may not provide information of direct relevance to the human gut ecosystem because of major differences in the composition of the microbiota between animals and humans. To circumvent such problems, germ-free animals have been associated with groups of bacteria from the human gut microflora. Such HFA animals provide an essential tool in studies of gut microbiology. They reflect the complexity of the microbial gut ecosystem in terms of species and numbers, and reproduce some of the biotic parameters provided by the mammalian mucosa, immune system and digestive functions. HFA animals provide an experimental system, allowing studies to be carried out that may not be conducted in human volunteers for ethical reasons. The role played by the human gut microflora in colon cancer has been mainly studied through experimental animals. Such studies have led to the identification of microbial enzyme activities involved in carcinogen production, and the demonstration of anti-tumour effects of prebiotics and probiotics in vivo (Goldin, 1986; Rowland \& Tanaka, 1993; Rafter, 1995; Gallaher et al. 1996; Rowland et al. 1996, 1998; Reddy, 1998). Recently, HFA and gnotobiotic animals have been used to generate data on DNA transfer events between members of the human gut microflora. These studies have highlighted the ability of promiscuous DNA elements (conjugative plasmids and transposons) to transfer between different species of bacteria and have also enabled some of the environmental factors governing such events to be established (Gruzza et al. 1994; Duval-Iflah et al. 1998; Tuohy, 2000). However, even in HFA animals generated using the faecal microflora of a single individual, subtle differences can occur in the microbial profile of the microflora. Gastrointestinal successional development, strain composition and local metabolic activities of the microbiota may differ between HFA animals and the human gut microflora used as inocula. It is important to realise the limits of both in vitro and in vivo models of the human gut and, where ethically sound, to use human 
volunteer trials for final demonstration of scientific principles such as the efficacy of a novel prebiotic.

\section{Molecular biology techniques}

To date, much of our understanding on the microbial ecology of the human gastrointestinal tract has been derived through microbiological culture. However, it is becoming increasingly apparent that there are serious limitations in the application of such techniques to complex microbial communities. Many bacteria present in the gut are fastidious, requiring very specific growth conditions, and are not readily amenable to microbial culture in the laboratory (Tannock, 1999). It has been estimated that less than $50 \%$ of species present in the gut microflora have been cultured on existing microbial growth media (Langendijk et al. 1995; Wilson \& Blitchington, 1996). The phylogenetic information encoded by 16S rRNA has enabled the development of molecular biology techniques, which allow characterisation of the whole human gut microbiota (Lawson, 1999). In the microbial ecology of the human gut, molecular techniques have found application for three main tasks: characterisation of microbial community composition; enumeration and monitoring of microbial population dynamics within communities; tracking of specific strains of bacteria in the gut microflora. In the following sections we discuss the application of selected molecular techniques to these three main tasks in relation to the impact of gastrointestinal microbial ecology in human health and disease.

\section{Characterisation of microbial community structure and composition}

Much information has been gained from the sequencing of bacteria isolated on selective agars using anaerobic microbiological techniques. However, as described above, only a fraction of the gut microflora may be cultured. Another drawback to this approach is that both traditional phenotypic and modern phylogenetic characterisation of individual bacteria are extremely labour intensive. The widespread application of modern phylogeny to studies of gut microbial ecology is dependent upon development of rapid, reliable and inclusive molecular techniques for identification of both culturable and non-culturable moieties of the gut microflora.

Direct community analysis PCR-rDNA whole community analysis allows the 16S rDNA diversity of environmental samples to be characterised. Total bacterial DNA is extracted directly and partial $16 \mathrm{~S}$ rDNA genes are amplified by polymerase chain reaction (PCR) employing universal bacterial primers (Suau et al. 1999; R Bonnet, A Suau, J Doré, GR Gibson and MD Collins, unpublished results). The amplification products are then purified and cloned into Escherichia coli. Clones containing 16S rDNA inserts are sequenced and compared with public databases of $16 \mathrm{~S}$ rDNA sequences. In this way, the bacteriological make-up of environmental samples can be determined in a culture-independent manner. PCR-rDNA whole community analysis, or comparative analysis of cloned 16S rRNA gene sequences, has been employed to characterise the faecal microflora of an adult human volunteer (Wilson \& Blitchington, 1996; Suau et al. 1999). Wilson \& Blitchington (1996) reported good agreement between the microbial diversity determined by culture techniques and direct PCR and cloning of whole community $16 \mathrm{~S}$ rDNA. A nine-cycle PCR was shown to give increased clone diversity compared with a 35-cycle PCR. More recently, Suau et al. (1999) employed comparative analysis of cloned 16S rRNA gene sequences to characterise the bacterial diversity of the adult faecal microflora. To maximise amplicon diversity, a ten-cycle PCR was used. The 
resultant 284 clones were grouped into eighty-two different molecular species based on a sequence homology of at least $98 \%$. Three phylogenetic groups dominated the clone library: the Bacteroides and Clostridium coccoides groups and the Clostridium leptum subgroup together accounted for $95 \%$ of all clones. The vast majority of $16 \mathrm{~S}$ rDNA sequences recovered did not correspond to any previously described and thus represented novel species of bacteria.

Owing to the high numbers of species present in adult faecal samples and the inherent bias introduced by PCR, some loss of bacterial diversity may be expected. R Bonnet, A Suau, J Doré, GR Gibson and MD Collins (unpublished results), have shown that the reduction of PCR cycles used in PCR-rDNA whole community analysis increases the diversity of 16S rDNA species recovered. The use of a wider range of both PCR conditions and primer specificities may increase the inclusivity of the approach. This powerful technique has the potential to characterise the make-up of the healthy human gut microflora and also to describe that of chronic intestinal complaints, where the flora is thought to affect disease aetiology or maintenance but where no direct correlation with specific bacteria has yet been drawn.

Denaturing gradient gel electrophoresis Denaturing gradient gel electrophoresis (DGGE) allows the separation of amplified DNA fragments of similar size based on the extent of sequence divergence between different PCR products (Muyzer \& Smalla, 1998). A single PCR reaction is carried out on whole community DNA and partial 16S rDNA sequences amplified from the different bacterial species present. DNA fragments of different sequence have varying temperatures. Fragments of the same size may be separated on gels that melt double-stranded DNA during electrophoresis, using a temperature or chemical denaturant gradient. Guanine and cytosine (GC) clamps may be added to the PCR products to enhance separation of fragments that differ in sequence by as little as one base pair (Sheffield et al. 1989). Sequences separated by DGGE may be identified by sequencing of fragments cut from the denaturing gradient gel or presumptively identified by comparing their motility with that of known control sequences (e.g. partial 16S rDNA gene sequences from a range of gut bacteria). DGGE has the potential to determine the identity of bacterial species present in complex microbial consortia without the need for prior sequence information. Thus, it provides a powerful tool in initial characterisation of both culturable and non-culturable populations in an ecosystem. Similarly, because of the rapidity of the technique, DGGE has potential in the monitoring of bacterial profiles within ecosystems over time, such as in the successional development and stability of the gut microflora (Zoentendal et al. 1998). Development of the infant microflora has been monitored using DGGE: profiles showed both transient occupation and colonisation of the gut by different bacteria in an individual specific manner (Vaughan et al. 2000). Moreover, Millar et al. (1996) employed DGGE of PCR-amplified partial 16S rDNA genes to characterise the microflora of preterm infants with and without NEC.

Problems associated with PCR-based molecular techniques Bias for specific nucleotide sequences may be introduced during PCR with universal primer pairs. Similarly, the efficiency of nucleic acid recovery from environmental samples and varying DNA denaturation conditions in different bacterial species will affect the PCR amplification of diverse target sequences. This is because bacterial species present different degrees of recalcitrance to enzymic, chemical and physical disruption techniques and varying GC contents (Wintzingerode et al. 1997; Vaughan et al. 2000). Biases introduced during PCR may be compounded when DGGE or temperature gradient gel electrophoresis are employed to characterise complex microbial samples: the more species present, the more bands to separate on a single electrophoresis gel. Species diversity may be underestimated by incomplete separation of amplicons upon 
D/TGGE. Similarly, bacterial species present in high numbers in samples have a better chance of being sufficiently amplified during PCR to enable clear band resolution, whereas subpopulations of bacteria may not give bands of sufficient intensity to allow clear banding and identification.

\section{Enumeration and monitoring of microbial population dynamics within communities}

Oligonucleotide probes specific for groups of bacteria or bacterial species may be designed using the phylogenetic information present in $16 \mathrm{~S}$ rRNA sequence databases. Such probes have been used to enumerate bacterial populations directly in environmental samples.

Dot-blot hybridisation Dot-blot hybridisation involves extraction of total 16S rRNA from environmental samples, binding total rRNA to a membrane and hybridising bound rRNA with labelled probes of varying specificity. Using probes for selected groups of bacteria and universal probes designed to hybridise with $16 \mathrm{~S}$ rRNA from all bacteria, an estimate of the contribution of selected groups of bacteria to the total 16S rRNA pool may be achieved by comparing the intensity of reporter molecules. As bacteria differ in ribosome content, depending on their metabolic activity and species, the ratio of bound group-specific probe to total bound probe is an estimate of bacterial numbers present and may not correlate directly with microbial numbers in situ. Dot-blot hybridisation has been used in studies of the rumen and to monitor the important human colonic Bacteroides-Porphyromonas-Prevotella phylogenetic group and Bifidobacterium spp. in the faecal microflora of infants (Stahl et al. 1988; Doré et al. 1998). Similarly, Sghir et al. (1998) used a suite of probes to monitor the selective nature of FOS for bifidobacteria and lactobacilli using a continuous-culture model of the human faecal microflora.

Fluorescent in situ hybridisation Fluorescent in situ hybridisation (FISH) employing oligonucleotide probes targeting 16S rRNA allows the enumeration of whole bacterial cells in situ in gastrointestinal and faecal samples (Amann et al. 1995; Zoentendal et al. 1998; Collins \& Gibson, 1999).

Genotypic probes targeting the predominant components of the gut microflora are tagged with fluorescent markers such that quantifiable changes in faecal/intestinal bacterial populations may be determined using fluorescence microscopy. FISH is a truly quantitative technique as it enumerates intact bacterial cells directly without extraction or amplification of nucleotide sequences. The major advantage of FISH is that bacterial populations may be enumerated in a culture-independent manner in environmental samples. Similarly, the technique allows visualisation of target bacterial cells in situ, for example in mucosal sections fixed in wax. A range of phylogenetic probes have been designed and validated for use in FISH, targeting groups of bacteria important in human health and disease, including Bifidobacterium spp. (Langendijk et al. 1995), Bacteroides spp. (Manz et al. 1996), Clostridium spp. (Franks et al. 1998) and the Lactobacillus/Enterococcus phylogenetic group (Harmsen et al. 2000). The use of FISH to enumerate such bacterial groups in the human faecal microflora has been validated against traditional microbiological culture techniques (Harmsen et al. 2000).

FISH is now finding application in the applied aspects of gastrointestinal microbial ecology. For example, Ames et al. (1999) used FISH to enumerate the dominant groups of the human gut microflora during in vitro batch-culture studies on the fermentability of melanoidins. Similarly, the prebiotic capabilities of lactulose powder and a final food product (biscuit) 
containing FOS and partially hydrolysed guar gum has been demonstrated in a double-blind placebo-controlled human feeding study using FISH for the bacteriology (K Tuohy, S Kolida, A Lustenberger and GR Gibson, unpublished results; K Tuohy, CJ Ziemer and GR Gibson, unpublished results). Such studies show the utility of the culture-independent FISH technique in monitoring changes in bacterial populations upon dietary supplementation. Microbial populations may be monitored in situ, providing information of direct relevance to the ecosystem under study. Previous studies characterising the prebiotic capabilities of oligosaccharides have relied upon traditional microbiological culture techniques. Such methodologies, as already discussed, may lead to inconsistencies due to the non-selectivity of so-called selective growth media. FISH, on the other hand, allows enumeration of specific groups of phylogenetically related bacteria. The technique has allowed direct visualisation of the group-specific augmentation of bifidobacterial numbers in human volunteers upon ingestion of lactulose at $10 \mathrm{~g} / \mathrm{d}$ for 26 days (K Tuohy, S Kolida, A Lustenberger and GR Gibson, unpublished results). Similarly, specific stimulation of bifidobacterial population levels in volunteers consuming biscuits containing FOS and partially hydrolysed guar gum has been shown, confirming that FOS retains prebiotic efficacy on processing into a commercial biscuit product (K Tuohy, S Kolida, A Lustenberger and GR Gibson, unpublished results; K Tuohy, CJ Ziemer and GR Gibson, unpublished results).

\section{Tracking of specific strains of bacteria in complex communities}

A major problem in determining the efficacy of probiotics is in demonstrating the survivability of probiotic strains in vivo in the human gut. It is often difficult to differentiate ingested probiotics from bacteria of the same (or closely related) species that may be present in the microbiota. DNA fingerprinting techniques, which take advantage of natural polymorphism in closely related genomic DNA or amplified 16S rRNA genes, have been applied to differentiate between ingested probiotic strains and members of the gut microflora (Kullen et al. 1997): DNA polymorphism became apparent upon digestion with restriction enzymes and resolution of resultant restriction fragments on electrophoresis gels. An array of DNA fingerprinting techniques (Vaneechoutte, 1996), employing both genomic and 16S rRNA, and DNA restriction fragment length polymorphism have been developed, e.g. pulsed-field electrophoresis, ribotyping, amplified ribosomal DNA restriction analysis and amplified fragment length polymorphism (McCartney \& Tannock, 1995; McCartney et al. 1996; O’Sullivan \& Kullen, 1998; Kullen \& Klaemhanner, 1999; Sharp \& Ziemer, 2000). Such techniques, capable of differentiation between closely related species to the species level and, in some cases, between strains of the same species, offer invaluable tools in tracking micro-organisms in the gut microflora. These approaches are being employed not only in probiotic feeding trials but also in fundamental studies examining the make-up of phylogenetic groups present in the gut microbiota.

Characterisation of the species composition of bifidobacteria and lactobacilli within the human gut will greatly influence understanding of the microbial ecology of these important groups of bacteria and allow health-promoting attributes of specific probiotic strains to be determined in an individual host-specific manner. Diagnostically powerful fingerprinting techniques are also being applied to epidemiological studies of pathogenic strains of bacteria. Gautom (1997) described a rapid method for identification of E. coli O157:H7 isolates based on pulsed-field electrophoresis. Development of such rapid protocols for existing DNA fingerprinting techniques will allow their routine use in medical microbiology. 


\section{Future developments}

Molecular biology techniques are now revolutionising studies in gut microbial ecology. For the first time, information on the species diversity and population profiles encompassing the vast majority of species present in ecological consortia may be obtained outside the constraints of microbiological culture techniques. Recent innovations, such as fluorescent marker systems (e.g. luciferase (lux) and green fluorescent protein $(g f p)$ ), FISH and in situ PCR (i.e. PCR of single-copy genes within bacterial cells), may allow characterisation of the biological activity of specific bacterial species in situ in environmental samples (Hodson et al. 1995; Tani et al. 1998; Drouault et al. 1999; Scott et al. 2000). A range of different reporter molecules are now commercially available. In the near future, studies combining FISH and in situ PCR may allow not only determination of species diversity and bacterial enumeration but allow visualisation of the activity of single-copy genes in bacterial cells in situ in environmental samples (Hodson et al. 1995; Tani et al. 1998). Such studies would be facilitated by the application of automated systems such as differential cell counting using flow cytometry (Wallner et al. 1995; Rice et al. 1997). Similarly, oligonucleotide microchips targeting $16 \mathrm{~S}$ rRNA or mRNA will allow an invaluable insight into the activities of the specific bacteria in complex microbial consortia (Guschin et al. 1997; Vaughan et al. 2000). Such techniques are being applied to the microbial ecology of the human gut and will hugely increase our understanding of the role played by the gut microflora in human health and disease. As such, dietary intervention will be placed on both a scientifically sound and a technologically advanced footing.

\section{References}

Alles MS, Hartemink R, Meyboom S, Harrywan JL, Van Laere KMHJ, Nagengast FM \& Hautvast GAJ (1999) Effect of transgalactooligosaccharides on the composition of the human intestinal microflora and on putative risk markers for colon cancer. American Journal of Clinical Nutrition 69, 980-991.

Allison C, McFarlan C \& Macfarlane GT (1989) Studies on mixed populations of human intestinal bacteria grown in single-stage and multistage continuous culture systems. Applied and Environmental Microbiology 55, $672-678$.

Amann RJ, Ludwig W \& Schleifer KH (1995) Phylogenetic identification and in situ detection of individual microbial cells without cultivation. Microbiology Reviews 59, 143-169.

Ames JM, Wynne AG, Hofmann A, Plos S \& Gibson GR (1999) The effect of a model melanoidin mixture in faecal bacterial populations in vitro. British Journal of Nutrition 82, 489-495.

Balsari A, Ceccarelli A, Dubini F, Fesce E \& Poli G (1982) The fecal microbial population in the irritable bowel syndrome. Microbiologica 5, 185-194.

Barry J-L, Hoebler C, Macfarlane GT, Macfarlane S, Mathers JC, Reed KA, Mortensen PB, Nordgaard I, Rowland IR \& Rumney CJ (1995) Estimation of the fermentability of dietary fibre in vitro: a European interlaboratory study. British Journal of Nutrition 74, 303-322.

Bearne CA, Mallett AK, Rowland IR \& Brennan-Craddock WE (1990) Continuous culture of human faecal bacteria as an in vitro model for the colonic microflora. Toxicology in Vitro 4, 522-525.

Bingham SA (1996) Epidemiology and mechanisms relating diet to risk of colorectal cancer. Nutrition Research Reviews 9, 197-239.

Bouhnik Y, Flourie B, Riottot M, Bisetti N, Gailing M, Guibert A, Bornet F \& Rambaud J (1996) Effects of fructooligosaccharides ingestion on fecal bifidobacteria and selected metabolic indexes of colon carcinogenesis in healthy humans. Nutrition and Cancer 26, 21-29.

Buddington RK \& Weiher E (1999) The application of ecological principles and fermentable fibers to manage the gastrointestinal tract ecosystem. Journal of Nutrition 29, 1446S-1450S.

Buddington RK, Williams CH, Chen SC \& Witherly SA (1996) Dietary supplement of neosugar alters the fecal flora and decreases activities of some reductive enzymes in human subjects. American Journal of Clinical Nutrition 63, $709-716$.

Butel MJ, Roland N, Hibert A, Popot F, Favre A, Tessedre AC, Bensaada M, Rimbault A \& Szylit O (1998) Clostridial pathogenicity in experimental necrotising enterocolitis in gnotobiotic quails and protective role of bifidobacteria. Journal of Medical Microbiology 47, 391-399.

Campbell H \& Jones I (1996) Promoting breastfeeding: a view of the current position and a proposed agenda for action in Scotland. Journal of Public Health Medicine 18, 406-414. 
Carlson SE (1985) N-acetylneuraminic acid concentrations in human milk oligosaccharides and glycoproteins during lactation. American Journal of Clinical Nutrition 41, 720-726.

Chadwick VS \& Anderson RP (1995) The role of intestinal bacteria in etiology and maintenance of inflammatory bowel disease. In Human Colonic Bacteria: Role in Nutrition, Physiology and Pathology, pp. 227-256 [GR Gibson and GT Macfarlane, editors]. Boca Raton: CRC Press.

Christl SU, Gibson GR, Murgatroyd PR, Sheppach W \& Cummings JH (1993) Impaired hydrogen metabolism in pneumatosis coli. Gastroenterology 104, 392-397.

Collins MD \& Gibson GR (1999) Probiotics, prebiotics and synbiotics: approaches for the nutritional modulation of microbial ecology. American Journal of Clinical Nutrition 69, 1052S-1057S.

Conway PL (1995) Microbial ecology of the human large intestine. In Human Colonic Bacteria: Role in Nutrition, Physiology and Pathology, pp. 1-18 [GR Gibson and GT Macfarlane, editors]. Boca Raton: CRC Press.

Coutts TM, Alldrick AJ \& Rowland IR (1987) Use of continuous culture to study the gastric microflora of a hypochlorhydric patient. Toxicology in Vitro 1, 17-21.

Dai D \& Walker WA (1998) Role of bacterial colonization in neonatal necrotizing enterocolitis and its prevention. Acta Paediatrica Sinica 39, 357-365.

De Leenheer L (1996) Production and use of inulin: industrial reality with a promising future. In Carbohydrates as Organic Raw Materials, vol. 3, pp. 67-92 [H Van Bekkun, H Roper and F Voragen, editors]. New York: Weinheim.

Doré J, Sghir A, Hannequart-Gramet G, Corthier G \& Pochart P (1998) Design and evaluation of a 16S rRNA-targeted oligonucleotide probe for specific detection and quantification of human faecal Bacteroides populations. Systematic and Applied Microbiology 21, 65-71.

Drouault S, Corthier G, Ehrlich SD \& Renault P (1999) Survival, physiology, and lysis of Lactococcus lactis in the digestive tract. Applied and Environmental Microbiology 65, 4881-4886.

Ducluzeau R \& Bensaada M (1982) Effet comparé de l'administration unique ou en continu de Saccharomyces boulardii sur l'establissement de diverses souches de Candida dans le tractus digestif de souris garotoxéniques. Annual Review of Microbiology 133, 149-151.

Duval-Iflah Y, Maisonneuve S \& Ouriet M-F (1998) Effect of fermented milk intake on plasmid transfer and on the persistence of transconjugants in the digestive tract of gnotobiotic mice. Antonie van Leeuwenhoek 73, 95102.

Edwards CA, Gibson G, Champ M, Jensen B-B, Mathers JC, Nagengast F, Rumney C \& Quehl A (1996) In vitro method for quantification of the fermentation of starch by human faecal bacteria. Journal of the Science of Food and Agriculture 71, 209-217.

Fooks LJ, Fuller R \& Gibson GR (1999) Prebiotics, probiotics and human gut microbiology. International Dairy Journal 9, 53-61.

Franks AH, Harmsen HJ, Raangs GC, Jansen GJ, Schut F \& Welling GW (1998) Variations of bacterial populations in human faeces measured by fluorescent in situ hybridization with group-specific 16S rRNA-targeted oligonucleotide probes. Applied and Environmental Microbiology 64, 3336-3345.

Freter R, Freter RR \& Brickner H (1983) Experimental and mathematical models of Escherichia coli plasmid transfer in vitro and in vivo. Infection and Immunity 39, 60-84.

Fujiwara S, Hashibara H, Hirota T \& Forstner JF (1997) Proteinaceous factor(s) in culture supernatant fluids of bifidobacteria which prevents the binding of enterotoxigenic Escherichia coli to gangliotetraosylceramide. Applied and Environmental Microbiology 63, 506-512.

Fuller R (1989) Probiotics in man and animals. Journal of Applied Bacteriology 66, 365-378.

Fuller R \& Gibson GR (1997) Modification of the intestinal microflora using probiotics and prebiotics. Scandinavian Journal of Gastroenterology 32, 28-31.

Gallaher DD, Stallings WH, Blessing LL, Busta FF \& Brady LJ (1996) Probiotics, cecal microflora, and aberrant crypts in the rat colon. Journal of Nutrition 26, 1362-1371.

Gautom RK (1997) Rapid pulsed-field gel electrophoresis protocol for typing of Escherichia coli O157:H7 and other Gram-negative organisms in 1 day. Journal of Clinical Microbiology 35, 2977-2980.

Gibson GR (1990) A review-The physiology and ecology of sulphate-reducing bacteria. Journal of Applied Bacteriology 69, 769-797.

Gibson GR \& Beaumont A (1996) An overview of human colonic bacteriology in health and disease. In Gut Flora and Health-Past, Present and Future, pp. 3-11 [AR Leeds and IR Rowland, editors]. London: The Royal Society of Medicine Press Ltd.

Gibson GR, Cummings JH \& Macfarlane GT (1988) Use of a three-stage continuous culture system to study the effect of mucin on dissimilatory sulfate reduction and methanogenesis by mixed populations of human gut bacteria. Applied and Environmental Microbiology 54, 2750-2755.

Gibson GR, Cummings JH \& Macfarlane GT (1991) Growth and activities of sulphate-reducing bacteria in gut contents from healthy subjects and patients with ulcerative colitis. FEMS Microbiology Ecology 86, 103-112.

Gibson GR \& McCartney AL (1998) Modification of gut flora by dietary means. Biochemical Society Transactions 26, $222-228$.

Gibson GR \& Macfarlane GT (1994) Intestinal bacteria and disease. In Human Health-The Contribution of Microorganisms, pp. 53-62 [SAW Gibson, editor]. London: Springer-Verlag.

Gibson GR, Ottaway PB \& Rastall RA (2000) Prebiotics: New Developments in Functional Foods. Oxford: Chandos Publishing Ltd. 
Gibson GR \& Roberfroid MB (1995) Dietary modulation of the human colonic microbiota: introducing the concept of prebiotics. Journal of Nutrition 125, 1401-1412.

Gibson GR \& Wang X (1994) Regulatory effects of bifidobacteria in the growth of other colonic bacteria. Journal of Applied Bacteriology 77, 412-420.

Goldin BR (1986) In situ bacterial metabolism and colon mutagens. Annual Review of Microbiology 40, $367-393$.

Goldin BR \& Gorbach SL (1984) The effect of milk and lactobacillus feeding on human intestinal bacterial enzyme activity. American Journal of Clinical Nutrition 39, 756-761.

Grizard D \& Barthomeuf C (1999) Non-digestible oligosaccharides used as prebiotic agents: mode of protection and beneficial effects on animal and human health. Reproduction Nutrition Developpement 39, 563-588.

Gruzza M, Fons M, Ouriet MF, Duval-Iflah Y \& Ducluzeau R (1994) Study of gene transfer in vitro and in the digestive tract of gnotobiotic mice from Lactococcus lactis strains to various strains belonging to human intestinal flora. Microbiology Releases 2, 183-189.

Guschin DY, Mobarry BK, Proudnikov D, Stahl DA, Rittmann BE \& Mirzabekov AD (1997) Oligonucleotide microchips as genosensors for determinative and environmental studies in microbiology. Applied and Environmental Microbiology 63, 2397-2402.

Harmsen HJM, Gibson GR, Elfferich P, Raangs GC, Wideboer-Veloo ACM, Argaiz A, Roberfroid MB \& Welling GW (2000) Comparison of viable cell counts and fluorescent in situ hybridization using specific rRNA-based probes for the quantification of human fecal bacteria. FEMS Microbiology Ecology 183, 125-129.

Hartemink R, Wolters FLH \& Rombouts FM (2000) Azoreductase activity in Lactobacillus rhamnosus. Poster Abstract, VTT Symposium 198, Functional Foods for EU Health in 2000, 4th workshop, FAIR CT 96-1028, PROBDEMO, Rovaniemi, Finland, 25-28 February, pp. 101-102. Available from VTT Information Service, PO Box 2000, FIN02044 VTT, Finland.

Hayatsu H \& Hayatsu T (1993) Suppressing effect of Lactobacillus casei administration on the urinary mutagenicity arising from ingestion of fried ground beef in the humans. Cancer Letters 73, 173-179.

Hentges DJ (1992) Gut flora and disease resistance. In Probiotics: The Scientific Basis, pp. 87-110 [R Fuller, editor]. London: Chapman and Hall.

Hodson RE, Dustman WA, Garg RP \& Moran MA (1995) In situ PCR for visualization of microscale distribution of specific genes and gene products in Prokaryotic communities. Applied and Environmental Microbiology 61, 40744082 .

Isolauri E, Arvilommi H \& Salminen S (1999a) Gastrointestinal infections. In Colonic Microbiota, Nutrition and Health, pp. 267-279 [GR Gibson and MB Roberfroid, editors]. Dordrecht: Kluwer Academic Publishers.

Isolauri E, Salminen S \& Mattila-Sandholm T (1999b) New functional foods in the treatment of food allergy. Annals of Medicine 31, 299-302.

King TS, Elia M \& Hunter JO (1998) Abnormal colonic fermentation in irritable bowel syndrome. Lancet 352, 11871189.

Kitajima H, Sumida Y, Tanaka R, Yuki N, Takayama H \& Fujimura M (1997) Early administration of Bifidobacterium breve to preterm infants: randomised controlled trial. Archives of Disease in Childhood 76, F101-F107.

Kleessen B, Sykura B, Zunft H-J \& Blaut M (1997) Effects of inulin and lactose on fecal microflora, microbial activity and bowel habit in elderly constipated persons. American Journal of Clinical Nutrition 65, 1397-1402.

Korpela R \& Saxelin M (1999) Probiotics and consumer products. In Colonic Microbiota, Nutrition and Health, pp. 281-289 [GR Gibson \& MB Roberfroid, editors]. Dordrecht: Kluwer Academic Publishers.

Kullen MJ, Amman MM, O’Shaughnessy MJ, O’Sullivan DJ, Busta FF \& Brady LJ (1997) Differentiation of ingested and endogenous bifidobacteria by DNA fingerprinting demonstrates survival of an unmodified strain in the gastrointestinal tract of humans. Journal of Nutrition 127, 89-94.

Kullen MJ \& Klaemhanner TR (1999) Genetic modification of intestinal lactobacilli and bifidobacteria. In Probiotics: a Critical Review, pp. 65-83 [GW Tannock, editor]. Wymondham, UK: Horizon Scientific Press.

Langendijk PS, Schut F, Jansen GJ, Raangs GW, Kamphuis GR, Wilkinson MHF \& Welling GW (1995) Quantitative fluorescent in situ hybridization of Bifidobacterium spp. with genus-specific 16S rRNA-targeted probes and its application in faecal samples. Applied and Environmental Microbiology 61, 3069-3075.

Lawson PA (1999) Taxonomy and systematics of predominant gut anaerobes. In Colonic Microbiota, Nutrition and Health, pp. 149-166 [GR Gibson \& MB Roberfroid, editors]. Dordrecht: Kluwer Academic Publishers.

Lee Y-K \& Salminen S (1995) The coming of age of probiotics. Trends in Food Science and Technology 6, $241-245$.

Levitt MD, Gibson GR \& Christl SU (1995) Gas metabolism in the large intestine. In Human Colonic Bacteria: Role in Nutrition, Physiology and Pathology, pp. 131-154 [GR Gibson \& GT Macfarlane, editors]. Boca Raton: CRC Press.

Levy J (1998) Immunonutrition: the pediatric experience. Nutrition 14, 641-647.

Lidbeck A, Overvidk E, Rafter J, Nord CE \& Gustafasson J-A (1992) Effect of Lactobacillus acidophilus supplements on mutagen excretion of feces and urine in humans. Microbial Ecology in Health and Disease 5, 59-67.

McCartney AL \& Tannock GG (1995) Ribotyping of Bifidobacterium strains using cells embedded in agarose plugs and a 16S rDNA probe. Microbial Ecology in Health and Disease 8, 79-84.

McCartney AL, Wenzhi W \& Tannock GW (1996) Molecular analysis of the composition of the Bifidobacterial and Lactobacillus microflora of humans. Applied and Environmental Microbiology 62, 4608-4613.

Macfarlane GT \& McBain AJ (1999) The human colonic microbiota. In Colonic Microbiota, Nutrition and Health, pp. 1-25 [GR Gibson and MB Roberfroid, editors]. Dordrecht: Kluwer Academic Publishers. 
Macfarlane GT, Macfarlane S \& Gibson GR (1998) Validation of a three-stage compound continuous culture system for investigating the effect of retention time on the ecology and metabolism of bacteria in the human colonic microbiota. Microbial Ecology 35, 180-187.

Macfarlane S, Cummings JH \& Macfarlane GT (1999) Bacterial colonisation of surfaces in the large intestine. In Colonic Microbiota, Nutrition and Health, pp.71-87 [GR Gibson and MB Roberfroid, editors]. Dordrecht: Kluwer Academic Publishers.

Macfarlane S, Quigley ME, Hopkins MJ, Newton DF \& Macfarlane GT (1998) Polysaccharide degradation by human intestinal bacteria during growth under multi-substrate limiting conditions in a three-stage continuous culture system. FEMS Microbiology Ecology 26, 231-243.

Majamaa H \& Isolauri E (1997) Probiotics: a novel approach in the management of food allergy. Journal of Allergy and Clinical Immunology 99, 179-186.

Manz W, Amann R, Ludwig W, Vancanneyt M \& Schleifer K-H (1996) Application of a suite of 16S rRNA-specific oligonucleotide probes designed to investigate bacteria of the phylum cytophaga-flavobacter-bacteroides in the natural environment. Microbiology 142, 1097-1106.

Michel C, Kravtchenko TP, David A, Gueneau S, Kozlowski F \& Cherbut C (1998) In vitro prebiotic effects of Acacia gums onto the human intestinal microbiota depends on both botanical origin and environmental pH. Anaerobe 4, 257-266.

Miksicek RJ (1995) Estrogenic flavonoids: structural requirements for biological activity. Proceedings of the Society for Experimental Biology and Medicine 208, 44-50.

Millar MR, Linton CJ, Cade A, Glancy D, Hall M \& Jalal H (1996) Application of 16S rRNA gene PCR to study bowel flora of preterm infants with and without necrotizing enterocolitis. Journal of Clinical Microbiology 34, 2506-2510.

Miller TL \& Wolin MJ (1981) Fermentation by the human large intestine microbial community in an in vitro semicontinuous culture system. Applied and Environmental Microbiology 42, 400-407.

Minekus M \& Havenaar R (1996) In vitro model of an in vivo digestive tract. United States Patent; nr. 5,525,305, dated 11 June 1996.

Modler HW (1994) Bifidogenic factors-sources, metabolism and applications. International Dairy Journal 4, 383407.

Molly K, Vande Woestyne M, De Smet I \& Vewrstraete W (1994) Validation of the simulator of the human intestinal microbial ecosystem (SHIME) reactor using microorganism-associated activities. Microbial Ecology in Health and Disease 7, 191-200.

Muyzer G \& Smalla K (1998) Application of denaturing gradient gel electrophoresis (DGGE) and temperature gradient gel electrophoresis (TGGE) in microbial ecology. Antonie Van Leeuwenhoek 73, 127-141.

Ofek I \& Doyle RJ (1994) Bacterial Adhesion to Cells and Tissues. New York: Chapman and Hall.

Onderdonk AB, Franklin ML \& Cisneros RL (1981) Production of experimental ulcerative colitis in gnotobiotic guinea pigs with simplified microflora. Infection and Immunity 32, 225-231.

O’Sullivan DJ \& Kullen MJ (1998) Tracking of probiotic bifidobacteria in the intestine. International Dairy Journal 8, 513-525.

Park SF \& Kroll RG (1993) Expression of listeriolysin and phosphatidylinositol-specific phospholipase C is repressed by the plant-derived molecule cellobiose in Listeria monocytogenes. Molecular Microbiology 8, 653661.

Parker TJ, Naylor SJ, Riordan AM \& Hunter JO (1995) Management of patients with food intolerances in irritable bowel syndrome: the development and use of the exclusion diet. Journal of Human Nutrition and Dietetics 8, 159166.

Peter CS, Feuerhahn M, Bohnhorst B, Schlaud M, Ziesing S, Von Der Hardt H \& Poets CF (1999) Necrotising enterocolitis: is there a relationship to specific pathogens? Paediatrics 158, 67-70.

Prescott LM, Harley JP \& Klein DA (1996) Human diseases caused primarily by Gram-positive and Gram-negative bacteria. In Microbiology, 3rd ed., pp. 766 [K Kane, editor]. London: William Brown Publishers.

Rafter JJ (1995) The role of lactic acid bacteria in colon cancer prevention. Scandinavian Journal of Gastroenterology 30, 497-502.

Reddy BS (1998) Prevention of colon cancer by pre- and probiotics: evidence from laboratory studies. British Journal of Nutrition 88, S219-S233.

Rice J, Sleigh MA, Burkill PH, Tarran GA, O'Connor CD \& Zubkov MV (1997) Flow cytometric analysis of characteristics of hybridization of species-specific fluorescent oligonucleotide probes to rRNA of marine nanoflagellates. Applied and Environmental Microbiology 63, 938-944.

Roberfroid MB (1998) Prebotics and synbiotics: concepts and nutritional properties. British Journal of Nutrition 80, S197-S202.

Rowland IR (1992) Metabolic interactions in the gut. In Probiotics: The Scientific Basis, pp. 29-53 [R Fuller, editor]. London: Chapman and Hall.

Rowland IR (1995) Toxicology of the colon: role of the intestinal microflora. In Human Colonic Bacteria: Role in Nutrition, Physiology and Pathology, pp. 155-174 [GR Gibson and GT Macfarlane, editors]. Boca Raton: CRC Press.

Rowland IR (1996) Gut microflora and cancer. In Gut Flora and Health-Past, Present and Future. International Congress and Symposium Series no. 219, pp. 19-25 [AR Leeds and IR Rowland, editors]. London: Royal Society of Medicine Press Limited. 
Rowland IR \& Tanaka R (1993) The effects of transgalactosylated oligosaccharides on gut flora metabolism in rats associated with a human faecal microflora. Journal of Applied Bacteriology 74, 667-674.

Rowland IR, Bearne CA, Fischer R \& Pool-Zobel BL (1996) The effect of lactulose on DNA damage induced by 1,2dimethylhydrazine in the colon of human-flora-associated rats. Nutrition and Cancer 26, 37-47.

Rowland IR, Rumney CJ, Coutts JT \& Lievense L (1998) Effect of Bifidobacterium longum and inulin on gut bacterial metabolism and carcinogen induced aberrant crypt foci in rats. Carcinogenesis 2, 281-285.

Rumney CJ \& Rowland IR (1992) In vivo and in vitro models of the human colonic flora. Critical Reviews in Food Science and Disease 31, 299-331.

Rumney CJ, Rowland IR, Coutts TM, Randerath K, Reddy R, Shah AB, Ellul A \& O’Neill IK (1993) Effects of riskassociated human dietary macrocomponents on processes related to carcinogenesis in human-flora-associated (HFA) rats. Carcinogenesis 14, 79-84.

Saavedra JM, Bauman NA, Oung I, Perman JA \& Yolken RH (1994) Feeding of Bifidobacterium bifidum and Streptoccus thermophilus to infants in hospital for prevention of diarrhoea and shedding of rotavirus. Lancet 344, $1046-1049$.

Sanders MA (1993) Summary of conclusions from a consensus panel of experts on health attributes of lactic cultures; significance to fluid milk products containing cultures. Journal of Dairy Science 76, 1819-1828.

Sanders MA (1998) Overview of functional foods: emphasis on probiotic bacteria. International Dairy Journal 8 , $341-347$.

Scott KP, Mercer DK, Richardson AJ, Melville CM, Glover LA \& Flint HJ (2000) Chromosomal integration of the green fluorescent protein gene in lactic acid bacteria and the survival of marked strains in human gut simulations. FEMS Microbiology Letters 182, 23-27.

Setchell DR (1998) Phytoestrogen: the biochemistry, physiology, and implications for human health of soy isoflavones. American Journal of Clinical Nutrition 68, 1333S-1346S.

Sghir A, Chow JM \& Mackie RI (1998) Continuous culture selection of bifidobacteria and lactobacilli from human faecal samples using fructooligosaccharide as selective substrate. Journal of Applied Microbiology 85, 769-777.

Sharp R \& Ziemer CJ (2000) Application of taxonomy and systematics to molecular techniques in intestinal microbiology. In Colonic Microbiota, Nutrition and Health, pp. 167-190 [GR Gibson and MB Roberfroid, editors]. Dordrecht: Kluwer Academic Publishers.

Sheffield VC, Cox DR, Lerman LS \& Myers RM (1989) Attachment of a 40-base-pair G + C rich sequence (GC-clamp) to genomic DNA fragments by the polymerase chain reaction results in improved detection of single-base changes. Proceedings of the National Academy of Sciences of the USA 86, 232-236.

Stahl DA, Flesher B, Mansfield HR \& Montgomery L (1988) Use of phylogenetically based hybridization probes for studies of ruminal microbial ecology. Applied and Environmental Microbiology 54, 1079-1084.

Stark PL \& Lee A (1982) The microbial ecology of the large bowel of breast-fed and formula-fed infants during the first year of life. Journal of Medical Microbiology 15, 189.

Suau A, Bonnet R, Sutren M, Godon J-J, Gibson GR, Collins MD \& Doré J (1999) Direct 16S rDNA community analysis reveals many novel molecular species within the human gut. Applied and Environmental Microbiology 65, $4799-4807$.

Sudo N, Sawamura S, Tanaka K, Aiba Y, Kubo C \& Koga Y (1997) The requirement of intestinal bacterial flora for the development of an IgE production system fully susceptible to oral tolerance induction. Journal of Immunology 159, $1739-1745$

Sütas Y, Soppi E, Korhonen H, Syväoja EL, Saxelin M \& Rokka T (1996) Suppression of lymphocyte proliferation in vitro by bovine caseins hydrolysed with Lactobacillus $G G$ derived enzymes. Journal of Allergy and Clinical Immunology 98, 216-224.

Tani K, Kurokawa K, and Nasu M (1998) Development of a direct in situ PCR method for detection of specific bacteria in natural environments. Applied and Environmental Microbiology 64, 1536-1540.

Tannock GW (1999) A fresh look at the intestinal microflora. In Probiotics: A Critical Review, pp. 5-14 [GW Tannock, editor]. Wymondham: Horizon Scientific Press.

Terada A, Hara H, Katoka M \& Mitsuoka T (1992) Effect of lactulose on the composition and metabolic activity of the human faecal flora. Microbial Ecology in Health and Disease 5, 43-50.

Tuohy K (2000) Measurement of DNA transfer in the gut using in vitro and in vivo models. PhD Thesis, University of Surrey, Guildford, UK.

Umesaki Y (1989) Intestinal glycolipids and their possible role in microbial colonisation of mice. Bifid Microflora 8 , $13-22$.

Vanderhoof J A \& Young R J (1998) Use of probiotics in childhood gastrointestinal disorders. Journal of Paediatric Gastroenterology and Nutrition 27, 323-332.

Vaneechoutte M (1996) DNA fingerprinting techniques for microorganisms. Molecular Biotechnology 6, $115-142$.

Van Loo J, Cummings J, Delzenne N, Englyst H, Franck A, Hopkins M, Kok N, Macfarlane G, Newton D, Quigley M, Roberfroid M, van Vliet T \& van den Heuvel E (1999) Functional food properties of non-digestible oligosaccharides: a consensus report from the ENDO (DGXII AIRII-CT94-1095). British Journal of Nutrition 81, 121 - 132.

Vaughan EE, Schut F, Heilig HGHJ, Zoetendal EG, de Vos WM \& Akkermans ADL (2000) A molecular view of the intestinal ecosystem. Current Issues in Intestinal Microbiology 1, 1-12.

Veilleux BG \& Rowland IR (1981) Simulation of the rat intestinal ecosystem using a two-stage continuous culture system. Journal of General Microbiology 123, 103. 
Wallner G, Erhart R \& Amann R (1995) Flow cytometric analysis of activated sludge with rRNA-targeted probes. Applied and Environmental Microbiology 61, 1859-1866.

Wang X \& Gibson GR (1993) Effects of the in vitro fermentation of oligofructose and inulin by bacteria growing in the human large intestine. Journal of Applied Bacteriology 75, 373-380.

Watanabe S \& Koessel S (1993) Colon cancer: an approach from molecular epidemiology. Journal of Epidemiology 2 , $47-61$.

Wilson KH (1993) The microecology of Clostridium difficile. Clinical Infectious Diseases 16, S214-S218.

Wilson KH \& Blitchington RB (1996) Human colonic biota studied by ribosomal DNA sequence analysis. Applied and Environmental Microbiology 62, 2273-2278.

Wintzingerode FV, Göbel UB \& Stackebrandt E (1997) Determination of microbial diversity in environmental samples: pitfalls of PCR-based rRNA analysis. FEMS Microbiology Reviews 21, 213-229.

Ziemer CJ \& Gibson GR (1998) Overview of probiotics, prebiotics and synbiotics in the functional food concept. International Dairy Journal 8, 473-479.

Zoentendal EG, Akkermans ADL \& De Vos WM (1998) Temperature Gradient Gel Electrophoresis analysis of 16S rRNA from human faecal samples reveals stable and host-specific communities of active bacteria. Applied and Environmental Microbiology 64, 3854-3859.

Zopf D \& Roth S (1996) Oligosaccharide anti-infective agents. Lancet 347, 1017-1021.

Zottola EA \& Smith LB (1990) The microbiology of foodborne disease outbreaks: an update. Journal of Food Safety 11, 13-29. 